IFN Working Paper No. 821, 2010

\title{
Local Economies and General Elections: \\ The Influence of Municipal and Regional Economic Conditions on Voting in Sweden 1985-2002
}

Mikael Elinder 


\title{
Local economies and general elections:
}

\section{The influence of municipal and regional economic conditions on voting in Sweden 1985-2002*}

\author{
Mikael Elinder
}

January 5, 2010

\begin{abstract}
This paper presents a detailed analysis of voters' responses to municipality and regional-level unemployment and economic growth, using panel data on 284 municipalities and 9 regions, covering Swedish general elections from 1982 to 2002. The preferred specification suggests that a reduction in regional unemployment by one percentage point is associated with an increase in the support for the national government by about 1.7 percentage points. The effect of growth, at the regional level, is substantial in size, but statistically insignificant. At the municipality level, unemployment has a smaller effect than at the regional level and growth has no effect on government support.
\end{abstract}

Keywords: elections, voting, local economic conditions JEL classifications: H11, R11, R12, R58

\footnotetext{
* I am grateful to Henrik Jordahl for his advice and encouragement. I would also like to thank Sören Blomquist, Niclas Berggren, Per-Anders Edin, Elly-Ann Johansson, Eva Mörk, Jenny Nykvist, Erik Post, Panu Poutvaara, Håkan Selin, David Strömberg and two anonymous referees, as well as seminar participants at Uppsala University, the Ratio Institute, and conference participants at the 2007 First World Meeting of the Public Choice Society, for valuable comments and suggestions. The Jan Wallander and Tom Hedelius Foundation is gratefully acknowledged for financial support.

\# The Research Institute of Industrial Economics (IFN), Stockholm, and Uppsala University, Department of Economics, P.O. Box 513 SE-75120 Uppsala.
} 


\section{Introduction}

Numerous empirical studies have shown that voters respond to economic conditions. These studies typically focus on national or individual level economic conditions. ${ }^{1}$ Only a handful of studies have estimated responses to local economic conditions. This is surprising for two reasons. First, a large theoretical literature uses the assumption that voters are sensitive to local economic conditions and, second, estimates of responses to other levels may be misleading if the responses to local level variables are substantial.

This paper improves the understanding of voting behavior by presenting a detailed analysis of responses to two different local levels of economic conditions. In particular, voters' responses to municipality and regional level unemployment and economic growth are estimated using data from six Swedish general elections between 1985 and 2002 covering 284 municipalities.

It is not a novel idea that voters consider local economic conditions when deciding whether to support the government or vote for the opposition. Models by e.g. Lindbeck and Weibull (1993) and Dixit and Londregan (1996) suggest that governments tactically redistribute resources to regions with many swing voters. Cox and McCubbins (1986) argue that politicians redistribute to regions where they have many supporters and Weingast et al. (1981) discuss how political effort and spending may be geographically uneven (and inefficient) if politicians favor their own constituencies. These models all assume that voters are sensitive to the amount of resources spent in their area and that resources are geographically unevenly redistributed.

A few empirical studies have found that voters respond to regional spending. Levitt and Snyder (1997) show that the outcomes of U.S. House elections are influenced by federal spending and Jordahl (2002) shows that voters respond to specific grants to Swedish municipalities from the national government. These tests have focused on spending rather than measures of economic outcomes. Funds come in a variety of forms and may have different effects on unemployment and economic growth. In this paper, I take a more general approach to this problem by estimating the impact of economic growth and unemployment, at local levels, on the support for the national government.

Knowing whether voters respond in systematic ways to economic conditions at local levels is important for understanding how voters respond to national and individual level economic conditions as well. Omitting local level variables may result in misspecified models and misleading estimates and conclusions. Earlier studies, only including national and individual level economic indicators, may therefore be missing important aspects of voting behavior.

Johnston and Pattie (2001) address this issue by including a local level in their analysis of the British general election of 1997, arguing that such an intermediate level is necessary for understanding voting behavior. They estimate the effect of individual, local, and national level economic conditions on individual voting behavior. Their study uses survey data on individuals' perceptions of economic conditions, and finds that voters are less influenced by perceptions of changes in national level economic prosperity than by perceptions of changes

\footnotetext{
${ }^{1}$ For surveys of the economic voting literature, see Lewis-Beck and Stegmaier (2000), Lewis-Beck and Paldam (2000) and Nannestad and Paldam (1994).
} 
in the prosperity of their local area. They also find that the prosperity of the local area influences voting behavior more than changes in the personal financial situation.

In a related study, Auberger and Dubois (2005) find that local economic circumstances play an important role in forecasting election outcomes in French legislative elections, using a measure of labor market performance as an indicator of local economic conditions. The aim of their study is mainly to make accurate predictions of election outcomes, while the aim of this paper is to understand at which levels voters respond to real changes in objective economic conditions. Furthermore, a key difference between the French and Swedish parliaments is that in the French National Assembly, representatives administrate local territories, while representatives in the Swedish Riksdag do not have such a clear local connection. This raises the question of whether local economic conditions have an impact on the vote also for political systems where national politicians do not have a direct responsibility for specific local areas.

Among other things, Leigh (2005) investigates how neighborhood characteristics influence citizens' partisan choice in Australian elections and finds that living in a richer neighborhood increases the probability of voting for the right-wing party. While that study focuses on a left-right choice, this paper focuses on a government-opposition choice.

Eisenberg and Ketcham (2004) ask a number of questions regarding voting in the United States. One question they try to answer is whether local economic conditions are of importance in U.S. presidential elections. They find that county-level economic conditions have a small impact on the election outcomes relative to state and national level economic variables. The results are not so surprising, given the great vertical distance between the national (federal) and the county level in the United States. This also makes it hard to draw any inference from this study to much smaller European countries.

Veiga and Veiga (2008) find that national economic conditions play a role in national elections in Portugal. Interestingly, they also find some influences of economic conditions at the municipality level.

Johnston and Pattie (2001), Auberger and Dubois (2005), Leigh (2005), and Veiga and Veiga (2008) all indicate that economic conditions between the national and the individual level influence how citizens vote.

Although the questions asked in Johnston and Pattie's (2001) study and in this paper are similar, a few differences are worth being pointed out. First, Johnston and Pattie analyze only one election, whereas I use data from six elections with much more variation in government performance. This also allows me to use a difference approach which effectively reduces the bias stemming from omitted variables.

While Johnston and Pattie use subjective perceptions of economic conditions and survey responses to how the respondents have voted, I use objective measures of economic conditions and real voting data. This avoids problems associated with measurement error and non-response in survey data. A possible advantage of their approach is that they use individual level data and perceptions of economic conditions. This also has some drawbacks, however. Since their respondents are asked to answer how their part of the country has developed, two problems arise. ${ }^{2}$ First, the respondents may differ in the size of the area they

\footnotetext{
${ }^{2}$ The question used by Johnston and Pattie (2001) to measure perceptions of local economic development is: "Compared with other parts of Britain since the last general election in April 1992, would you say that (this part
} 
consider. Second, even if the respondents have concordant perceptions of what they mean with this part of Britain, the researcher does not know if most people are referring to the village they live in or if they think of regions with many millions of people. I avoid these problems by using economic variables at well defined levels of aggregation, viz. municipalities and regions based on the area covered by the regional news, as broadcasted by Swedish public television.

Another well-known problem of using subjective perceptions of economic changes as explanatory variables is that a large proportion of the variation may be unrelated to variation in their objective counterparts. As a consequence, estimates based on subjective perceptions may suffer from a severe attenuation bias, thus making it difficult to know if real changes in the objective variables influence voting decisions (Kramer, 1983). Subjective perceptions of economic conditions have also been shown to be related to many confounding factors such as political attitudes, education and media exposure (Duch et al., 2000), making it even more difficult to know how real economic changes affect the support of the incumbent government. For further discussions on these questions, see e.g. Kramer (1983), Kirchgässner (1991), Nannestad and Paldam (1997), and Duch et al. (2000). Although voters must base their decisions on their perceptions of economic conditions, it may be more interesting to know how they respond to real economic conditions.

This paper improves on the existing literature on the influences of local economic conditions by analyzing responses to objective measures of economic conditions at two different local levels, using panel data covering six elections. In addition, I expose the results to extensive robustness tests. Furthermore, previous analyses of responses to local economic conditions have used British, French, Portuguese, Australian, and American data, but no study has investigated Swedish data.

The empirical results of this paper indicate substantial responses to local level economic conditions. The preferred specification suggests that a reduction in regional unemployment by one percentage point is associated with an increase in the support for the national government by about 1.7 percentage points. The effect of growth, at the regional level, is substantial in size, but statistically insignificant. At the municipality level, unemployment seems to have a smaller effect than at the regional level and growth has no effect on government support.

Exposing the model to extensive robustness tests provides further insights, but does not change the main conclusion that voters respond to local level economic conditions.

\section{Theoretical background}

In addition to the papers by Weingast et al. (1981) and Dixit and Londregan (1996), which directly suggest that support for the government may be influenced by local economic conditions, there are many models of voting and political behavior that also suggest that local economic conditions may be important.

The economic voting literature builds on early contributions by Downs (1957) and Key (1966). They both argue that voters hold the incumbent government responsible for economic conditions in the sense that they reward a government that has been successful in its economic policies by reelecting it. Downs (1957) motivated this retrospective economic voting theory with the observation that the policies of political parties tend to be rather stable over time.

of Britain/Scotland/Wales) has been getting more prosperous than average, stayed about the average, or been getting less prosperous than average?" 
Models of rational retrospective voting have been formalized by Rogoff and Sibert (1988) and Persson and Tabellini (1990), showing that past outcomes of economic variables can be used as signals of the economic competence of the government.

Economic models of voting typically assume that voters are selfish ${ }^{3}$, while many political scientists instead argue that voters have altruistic voting motives. However, it is hard to test to what degree voters are selfish or altruistic. Empirical studies typically suggest that voters respond to national level indicators of economic conditions, while only a few find important responses to microeconomic conditions. ${ }^{4}$ Responses to macroeconomic conditions are, however, consistent both with altruistic concerns and selfish motives. For example, a voter that responds to macroeconomic variables may do so because she believes it to be a good indicator of how her own personal financial situation will develop if the incumbent government is reelected, or because she is concerned about the economic situation of all citizens in the country. Furthermore, Brennan and Lomasky (1993) argue that citizens who are otherwise selfish may very well express altruism when casting their vote. The reason is that the cost of altruistic voting is negligible since the probability of affecting the outcome of the election is very small.

As shown by the discussion, no theoretical consensus of why citizens vote as they do has been reached and the empirical literature has not been able to clearly discriminate between the models. Most of the models do, however, suggest that citizens base their voting decisions at least partly on the success of the government's economic policy.

Few of the models discussed above explicitly suggest on which economic indicators voters should base their decision and none of them seem to conflict with the hypothesis that voters also consider local economic conditions. Some of them may actually work better with local economic indicators since voters who are purely selfish may find that local economic conditions could be more useful in predicting personal financial outcomes than national economic conditions. Altruistic voters may, on the other hand, care relatively more about people living closer to them and, therefore, also have reasons to consider local economic conditions. In line with this, I specify the econometric model so as to allow voters to respond to past economic conditions at two different local levels. The aim is not to discriminate between the different models but purely to investigate the empirical relationships between economic conditions at local levels and government support.

\section{Institutional and geographical settings}

The Swedish political system is organized into three levels: municipalities, counties and the national level. All levels set and collect taxes as well as supply services to citizens. The municipalities supply services such as primary and secondary education, child care, and social assistance, while the main task of the counties is to supply medical service. Elections, at all levels, were held on the same day every three years from 1970 until 1994, and every four years since 1994 .

\footnotetext{
${ }^{3}$ However, there are models that do not rely on this assumption. In papers by, for example, Blomquist and Christiansen (1999), and Dixit and Londregan (1998) citizens that are allowed to have altruistic preferences vote over the supply of publicly provided private goods and redistribution.

${ }^{4}$ For a review, see Lewis-Beck and Stegmaier (2000) and Nannestad and Paldam (1994). Examples of papers finding responses to macroeconomic variables are: Kramer (1971), Kinder and Kiewiet (1979) and Markus (1988). Examples of papers finding responses to microeconomic variables are: Nannestad and Paldam (1997), Markus (1988) and Jordahl (2006).
} 
The focus of this study is on the general election, i.e. the election to the Swedish parliament. ${ }^{5}$ A proportional system is used to allocate seats in parliament, which then appoints a Prime Minister to form a government. The government can consist of a single party or a coalition of parties and the parties are usually divided into a left- and a center-right bloc. During the time period for this analysis, the center-right bloc formed a coalition government between 1991 and 1994 and the Social Democratic Party (Socialdemokraterna) ruled as a minority government during five terms (1982-1991 and 1994-2002). The Social Democratic Party has generally been supported by the Left Party (Vänsterpartiet). For extended periods, the Green Party (Miljöpartiet) and the Center Party (Centerpartiet) also cooperated with the Social Democratic Party, and other parties have, at times, lent the Social Democratic Party pivotal support on specific issues.

It is natural to investigate responses to municipality-level economic conditions, as these are likely to have a direct impact on the well-being of many citizens. It is also likely that many voters are well informed about the economic conditions in their own municipality, since many sources for that kind of information are available, such as local newspapers and regular interactions with other people in the municipality. ${ }^{6}$ Whether voters hold the central government responsible for the municipal economic conditions is, however, less clear and will be investigated in this paper. In 1990, 90 percent of the municipalities had a population of between 6,000 and 88,000 citizens. The municipality of Stockholm (the capital of Sweden) clearly stands out in this dimension with almost 700,000 citizens. As the capital of Sweden, Stockholm is different from other municipalities also in many other dimensions. For instance, as virtually all media in Sweden report on the economic conditions in Stockholm, people living in Stockholm are likely to have more accurate information about the economic conditions in their municipality than what other citizens have about their home municipalities.

Many people live in one municipality and work in another. Figures from Statistics Sweden show that an average of 24 percent of the working population works in another municipality than the one in which they live. In 10 percent of the municipalities, this share was above 50 percent. Substantial commuting indicates that people may be affected by economic conditions in municipalities other than their home municipality. This observation also motivates the investigation of voting responses to regional economic conditions.

Ideally, one would like regions to be sufficiently large so that the economic conditions in the municipalities may differ from those of the region. One would also like the region to be a natural region in the sense that citizens have common perceptions of what constitutes the region. Furthermore, it is important that citizens can easily obtain information about economic conditions in the region.

One type of region that meets the above criteria is the regions defined by the coverage areas of 'the regional news' (Regionala nyheter). Swedish public television (Sveriges Television $\mathrm{AB}$ ) broadcasts regional news on a daily basis and has done so during the entire period covered in this paper. The regional news is an important source of information about the regional economy. Every day, about ten percent of the population watch the regional

\footnotetext{
${ }^{5}$ Several studies have shown that economic voting plays an important role in Sweden; for a brief survey of these studies see Jordahl (2006).

${ }^{6}$ Daily newspapers are an important source of information in Sweden. Annual estimates from 1986 to 2001 show that between 80 and 90 percent of the adult population read a daily newspaper at least five days per week (Antoni and Eriksson, 2002). Near all of the about 170 daily newspapers in Sweden have a local connection and serve one or a few municipalities, devoting a substantial part of the newspaper to local news.
} 
news. This means that citizens within each region have a common important source of information concerning the economic situation of the region. During the period of study, nine different programs were broadcasted, each covering a geographically connected area consisting of a specified set of municipalities. This makes the coverage areas of the regional news natural areas to use as regions in this investigation. ${ }^{7}$ Consequently, these regions will serve as the regional level in the empirical analysis. For further details about the regions, see appendix B.

An alternative to using media regions would be to use the counties as regions. At least one aspect of the counties makes them less appealing to use as regions in this analysis. Since each county encompasses fewer municipalities than the media regions, the variables of economic conditions are to a very high degree correlated between the municipalities and the county. This makes it difficult to estimate responses to both levels with a reasonable degree of precision.

\section{Data}

This paper uses a dataset consisting of a panel of 284 out of 290 Swedish municipalities ${ }^{8}$, covering six general elections from 1985 to $2002 .{ }^{9}$ The time period is constrained backwards because of lack of unemployment data for municipalities. The fundamental variables needed for the regression analysis are election results at the municipality level for the general election and measures of economic conditions at the municipality and the regional level.

The dependent variable is defined as the change in the vote share (since the preceding election expressed in percentage units) of the governing party or parties. As mentioned above, the Social Democratic Party has been ruling as a minority government but has been collaborating with other parties. This makes it difficult to fully ascertain which parties bear the responsibility for the economic policy. Therefore, I will also, as most studies of economic voting in Sweden, use the change in the vote share of the governing bloc as the dependent variable. $^{10}$

Although there are different ways of measuring economic conditions, I will follow most researchers in the economic voting literature and use measures of income growth and unemployment. The variables measured at the municipality level are real growth in the per capita tax base $\mathrm{e}^{11}$ and the unemployment rate ${ }^{12}$. The measures of unemployment and economic growth at the regional level are aggregated from data at the municipality level and calculated as the averages of their counterparts in all municipalities in the region, weighted by

\footnotetext{
${ }^{7}$ The nine regions used on average encompass about 32 municipalities and 2.5 counties.

${ }^{8}$ The six newly founded municipalities that have been omitted are (year founded in parentheses): Bollebygd (1995), Gnesta (1992), Knivsta (2003), Lekeberg (1995), Nykvarn (1999) and Trosa (1992).

${ }^{9}$ The elections occurred in 1985, 1988, 1991, 1994, 1998 and 2002.

${ }^{10}$ See e.g. Alesina et al. (1997) and Jordahl (2006). The left bloc consists of the Social Democratic Party (Socialdemokraterna), the Left Party (Vänsterpartiet) and the Green Party (Miljöpartiet). The center-right bloc consists of the Moderate Party (Moderaterna), the Center Party (Centerpartiet), the Liberal Party (Folkpartiet), the Christian Democrats (Kristdemokraterna) and the New Democrats (Ny Demokrati).

${ }^{11}$ Change in the tax base is the most commonly used measure of economic growth in Swedish municipalities. However, it should be noted that there was as change in the definition of the tax base in conjunction with the tax reform of 1991. After the reform, only labor income is included in the tax base measure, while both capital and labor incomes were included before the reform. Nevertheless, it is still the best measure available.

${ }^{12}$ This measure is the best available measure of unemployment at the municipality level, since it is measured in the same way both across municipalities and time. It is calculated as the number of unemployed divided by the population aged 16-64, and does therefore not correspond to the unemployment rate traditionally used by labor economists, but is more closely connected to the inverse of the employment rate.
} 
population. For detailed descriptions of all variables and descriptive statistics, see Appendix A.

\section{Empirical investigation}

\subsection{Model and empirical strategy}

Most estimates in the economic voting literature are based on linear equations specified either in levels or changes. ${ }^{13}$ Two particular features of this study make a model specified in changes preferable. First, one advantage of estimating a first difference equation is that covariates that are time invariant cancel out and hence, reduce the potential bias stemming from unobserved time-invariant characteristics. Second, the different governments in Sweden have been of different sizes since the Social Democratic Party has been ruling as a minority government, while the center-right bloc has formed coalition governments consisting of three or four parties. By focusing on the changes in the vote share of the incumbent government, instead of the level of the support, the fact that the support for left and the center-right governments has fluctuated around different levels becomes less problematic. This latter aspect makes a first difference model preferable to a fixed-effects model, which would utilize deviations from the mean support of both left and center-right governments to estimate the coefficients. It also makes a random effects model inappropriate to use, since the distribution of municipality-specific effects is unlikely to be normally distributed when both left and center-right governments are included in the dependent variable.

While the dataset I use is well suited for estimating responses to local level economic conditions, it is unfortunately not suited for estimating responses to national level economic conditions. The problem is that with only six elections, there are only six different observations of macro variables, which leads to a low precision in the estimates. The standard errors become large and the estimates become sensitive to unusual values in national level variables. Furthermore, since national level variables per definition are constant across municipalities, it is only possible to include a maximum of one macro variable per election in the specification. This is troublesome since many factors at the macro level, such as inflation, evolution of government debt, election specific issues, candidate effects etc, have been shown to affect election outcomes. For such an analysis, either a longer time-series or perceptions of economic conditions would be needed. ${ }^{14}$ In this case, the most general way of controling for macroeconomic conditions is to include year dummies. Wooldridge (2002, p. 129) suggests that year dummies should generally be used to account for aggregate changes over time when pooled cross sections are analyzed. If any variables at the national level are included in the regressions some year dummies need to be dropped. However, it is hard to argue why one year dummy should be included but not another. I argue that the best way of controling for these factors is to add a full set of year dummies as explanatory variables. Year dummies capture the average effect of omitted macro variables and since, by definition, the macro variables take the same values for all cross-sectional units, their effect is uniform and hence

\footnotetext{
${ }^{13}$ See Nannestad and Paldam (1994).

14 Veiga and Veiga (2008) find that macroeconomic variables have a larger influence than local economic conditions on voting in Portugal. Johnston and Pattie (2001) find that economic conditions at the regional level have a much larger influence than economic conditions at the national level in the United Kingdom.
} 
coincides with the average effect. Adding year dummies instead of specific macro variables will therefore not bias the estimates of the effects at the municipality and regional level. Unfortunately, this comes at the cost of its no longer being possible to include the macro variables of interest, i.e. unemployment and growth. While a comparison with the effect of national level variables will not be feasible, the effects of municipality and regional level variables will not be biased due to the omission of variables at the macro level.

Specifying the model in first difference and adding year dummies yields the following regression equation:

$$
\Delta V_{i, t}=\beta^{M} \Delta G_{i, t}{ }^{M}+\gamma^{M} \Delta U_{i, t}{ }^{M}+\beta^{R} \Delta G_{i, t}{ }^{R}+\gamma^{R} \Delta U_{i, t}{ }^{R}+Y D_{t}+Z_{i, t}^{\prime} \Phi+\varepsilon_{i, t},
$$

where subscript $i$ refers to municipality $i$, and $t$ to the election at year $t . \Delta V_{i, t}$ hence denotes the change in the vote share of the incumbent government from municipality $i$ at election $t$, since the last election. $\Delta G$ refers to a change in economic growth and $\Delta U$ to a change in unemployment. Superscripts $M$ and $R$ refer to the municipality and regional level. $Y D_{t}$ are election specific dummies, $Z^{\prime}$ is a row vector of time variant covariates, and $\varepsilon$ is an error term.

The measures of economic conditions at the regional level are, by construction, correlated with their counterparts at the municipality level. This can lead to problems with multicollinearity. Table 1 shows a matrix of correlation coefficients for changes in unemployment and growth at the regional and municipality level.

Table 1

Correlation coefficients

\begin{tabular}{lllll}
\hline & $\Delta \mathrm{G}_{\mathrm{R}}$ & $\Delta \mathrm{U}_{\mathrm{R}}$ & $\Delta \mathrm{G}_{\mathrm{M}}$ & $\Delta \mathrm{U}_{\mathrm{M}}$ \\
\hline$\Delta \mathrm{G}_{\mathrm{R}}$ & 1.000 & & & \\
$\Delta \mathrm{U}_{\mathrm{R}}$ & -0.521 & 1.000 & & \\
$\Delta \mathrm{G}_{\mathrm{M}}$ & 0.901 & -0.459 & 1.000 & \\
$\Delta \mathrm{U}_{\mathrm{M}}$ & -0.525 & 0.962 & -0.462 & 1.000 \\
\hline
\end{tabular}

As can be seen, the correlations between corresponding measures at the different levels are very high, while the correlation between changes in unemployment and growth within each level is more modest. ${ }^{15}$ When regressors are highly correlated, the estimated standard errors become large as it becomes difficult to know which of the correlated regressors that explain the variation in the dependent variable. As a consequence, confidence intervals for the parameters in the model tend to be large, which makes it difficult to obtain reasonable levels of precision in hypotheses testing of the model parameters. However, it should be noted that although the confidence intervals may be large, the estimated coefficients are still unbiased, as long as the model is correctly specified. Several methods for dealing with problems of multicollinearity have been proposed, such as extending the sample, transforming variables, dropping some variables from the model, or using the ridge-regression estimator. Except for extending the sample and transforming variables these methods all risk biasing the estimates of interest (Greene, 2003, p 56-59). In the words of Davidson and MacKinnon (2004, p. 102-103): "Collinearity can cause difficulties for applied econometric work, but these

\footnotetext{
${ }^{15}$ All correlations are statistically significant at the one-percent level.
} 
difficulties are essentially the same as the ones caused by having a sample size that is too small". Even if some regressors are highly correlated, it is possible to obtain estimates that are sufficiently precise for our purpose if the sample is sufficiently large, or if the error variance of the model is small. However, in presence of other sources of bias ${ }^{16}$, multicollinearity may aggravate those biases. This type of problem may be present even if the variables of interest seem to be precisely estimated. As a consequence, I carefully investigate how correlation between the explanatory variables influences the results. I do this by testing for multicollinearity and by presenting results based on different specifications - including specifications in which municipality level economic conditions have been transformed to mitigate multicollinearity problems. I test for multicollinearity by regressing each of the four measures of economic conditions on the other three measures and a constant. The baseline results in Table 2 show R-squared for these regressions. The R-squares are in all cases high, which further indicates that multicollinearity may be a problem in the present application. However, problems with multicollinearity can be mitigated by transforming the municipality level economic conditions to capture deviations from the corresponding measure at regional level. This transformation dramatically reduces the correlation between the explanatory variables without introducing new sources of bias. The second row of Table 2 shows R-square measures for the multicollinearity tests after transformation of municipality level economic conditions. As all R-square measures are much lower after transformation, it indicates that this type of transformation is useful for avoiding problems with multicollinearity. ${ }^{17}$ In the empirical investigation I show results based both on original and on transformed measures of municipality economic conditions.

Table 2

Testing for multicollinearity by examining $\mathrm{R}^{2}$ from auxiliary regressions

\begin{tabular}{lllll}
\hline Dep. Var. & $\Delta \mathrm{G}_{\mathrm{R}}$ & $\Delta \mathrm{U}_{\mathrm{R}}$ & $\Delta \mathrm{G}_{\mathrm{M}}$ & $\Delta \mathrm{U}_{\mathrm{M}}$ \\
\hline Baseline & 0.831 & 0.928 & 0.813 & 0.927 \\
After transformation & 0.290 & 0.298 & 0.018 & 0.019 \\
\hline
\end{tabular}

Note: Each of the four columns presents $\mathrm{R}^{2}$ for a regression in which the specified economic condition is regressed on the other three measures plus a constant. In the bottom line measures of municipality level economic conditions have been transformed by subtracting the corresponding measure at the regional level.

The municipalities differ in the number of voters. If each municipality is given the same weight in the estimations, the results should be interpreted as the effect of economic conditions in the typical municipality. If we are instead interested in how the typical voter reacts, then we need to weight the observations according to the number of voters in each municipality. Since each citizen's vote is given equal weight in the election and we are equally interested in the voting behavior of people in all municipalities, it is natural to give each vote equal weight in the regressions as well. The weights are calculated as each municipality's share of the number of votes in the election. Thus, larger municipalities will be given higher weights than small municipalities. It should be noted that if voting behavior is homogeneous across municipalities of different sizes, which is implicitly proposed by the empirical specification, the weighted and non-weighted regressions should produce similar results.

\footnotetext{
${ }^{16}$ Such as for example bias stemming from misspecification of the model.

${ }^{17}$ I thank one of the reviewers for suggesting this method for dealing with the multicollinearity problem.
} 


\subsection{Basic results}

This section presents estimates of the effects of unemployment and growth at the regional and municipality level, based on the model described in the previous section. The results are derived with the change in the governing parties' vote share as the dependent variable. The change in economic growth is measured as the difference between the average growth rate over the present and the previous term of office. The change in unemployment is calculated in the same way.

Table 3 shows results from six different specifications. In all specifications the observations are weighted according to the number of voters in the municipality. As previously mentioned, multicollinearity may potentially be a concern. To be able to assess whether multicollinearity is a critical problem for the analysis, I first include economic conditions at the regional level only, and then municipality level economic conditions only, and finally economic conditions at both levels simultaneously. The results are compared with each other. If multicollinearity causes severe problems, I expect the estimates to vary excessively between regressions and to be imprecisely estimated.

Column 1 presents the results when only economic conditions at the regional level are included in the model and column 2 when only economic conditions at the municipality level are included. The results point at substantial and statistically significant responses to unemployment both at the regional and municipality levels. Growth, both at the regional and municipality levels, seem to have small or no effects on the support of the governing parties. Given that changes in economic conditions at the two levels are highly correlated, we need to be careful in interpreting these coefficients since we cannot yet be confident that they capture responses to economic conditions at the intended level only. If economic conditions at both levels influence voting in the national elections, we need to include measures of economic conditions at both levels simultaneously in order to avoid biasing the parameter estimates. This is done in column 3, where economic conditions at both levels are included simultaneously. The estimates are quite similar to those in columns 1 and 2 , although the point estimates indicate slightly smaller responses to unemployment at both the regional and the municipal level. The impression of including economic conditions at both levels at the same time is that the estimates are reasonably stable and precisely estimated. To further investigate how the results are affected by the high correlation of economic conditions between the two levels, I transform the measures of economic conditions at the municipality level to capture deviations from the regional level. This procedure dramatically reduces the correlations between the different measures of economic conditions and increases the precision of the estimates. Column 4 presents the results based on this transformation. The effect of growth at the regional level is virtually unchanged, while the standard errors become slightly smaller. Both the effect of unemployment and the precision of the estimate, at the regional level, increase as a result of this transformation. At the municipality level both the effects and the standard errors are unchanged. 
Table 3

Local level economic conditions and government support

\begin{tabular}{|c|c|c|c|c|c|c|}
\hline Dep. Var. & $\begin{array}{l}(1) \\
\Delta \text { Gov }\end{array}$ & $\begin{array}{l}(2) \\
\Delta \text { Gov }\end{array}$ & $\begin{array}{l}(3) \\
\Delta \mathrm{Gov}\end{array}$ & $\begin{array}{l}(4) \\
\Delta \mathrm{Gov} \\
\end{array}$ & $\begin{array}{l}(5) \\
\Delta \text { Gov }\end{array}$ & $\begin{array}{l}\text { (6) } \\
\Delta \text { Gov } \\
\end{array}$ \\
\hline$\Delta \mathrm{G}_{\mathrm{R}}$ & $\begin{array}{l}0.162 \\
(0.226)\end{array}$ & & $\begin{array}{l}0.161 \\
(0.237)\end{array}$ & $\begin{array}{l}0.162 \\
(0.228)\end{array}$ & $\begin{array}{l}0.382 \\
(0.251)\end{array}$ & $\begin{array}{l}0.255 \\
(0.234)\end{array}$ \\
\hline$\Delta \mathrm{U}_{\mathrm{R}}$ & $\begin{array}{l}-1.660 * * * \\
(0.412)\end{array}$ & & $\begin{array}{l}-1.230 * * * \\
(0.474)\end{array}$ & $\begin{array}{l}-1.658 * * * \\
(0.417)\end{array}$ & $\begin{array}{l}-1.711^{* * * *} \\
(0.339)\end{array}$ & $\begin{array}{l}-1.625^{* * * *} \\
(0.397)\end{array}$ \\
\hline$\Delta \mathrm{G}_{\mathrm{M}}$ & & $\begin{array}{l}0.0301 \\
(0.0536)\end{array}$ & $\begin{array}{l}0.00146 \\
(0.0532)\end{array}$ & & & \\
\hline$\Delta \mathrm{U}_{\mathrm{M}}$ & & $\begin{array}{l}-0.623 * * * \\
(0.0884)\end{array}$ & $\begin{array}{l}-0.428^{* * * *} \\
(0.105)\end{array}$ & & & \\
\hline$\Delta \mathrm{G}_{\mathrm{M}}($ transformed $)$ & & & & $\begin{array}{l}0.00146 \\
(0.0532)\end{array}$ & $\begin{array}{l}0.00222 \\
(0.0388)\end{array}$ & $\begin{array}{l}-0.0172 \\
(0.0358)\end{array}$ \\
\hline$\Delta \mathrm{U}_{\mathrm{M}}($ transformed $)$ & & & & $\begin{array}{l}-0.428 * * * \\
(0.105)\end{array}$ & $\begin{array}{l}-0.427 * * * \\
(0.118)\end{array}$ & $\begin{array}{l}-0.361 * * * \\
(0.117)\end{array}$ \\
\hline$\Delta \mathrm{G}_{\mathrm{R}} \times$ Same inc. & & & & & & $\begin{array}{l}-0.245^{* * * *} \\
(0.0888)\end{array}$ \\
\hline$\Delta \mathrm{U}_{\mathrm{R}} \times$ Same inc. & & & & & & $\begin{array}{l}0.0533 \\
(0.0515)\end{array}$ \\
\hline$\Delta \mathrm{G}_{\mathrm{M}} \times$ Same inc. & & & & & & $\begin{array}{l}-0.00408 \\
(0.140)\end{array}$ \\
\hline$\Delta \mathrm{U}_{\mathrm{M}} \times$ Same inc. & & & & & & $\begin{array}{l}-0.107 \\
(0.195)\end{array}$ \\
\hline Same incumbent & & & & & & $\begin{array}{l}0.102 \\
(0.255)\end{array}$ \\
\hline$\Delta$ foreign & & & & & $\begin{array}{l}0.254 * \\
(0.137)\end{array}$ & $\begin{array}{l}0.209 \\
(0.138)\end{array}$ \\
\hline$\Delta$ old & & & & & $\begin{array}{l}-0.275^{* * * *} \\
(0.100)\end{array}$ & $\begin{array}{l}-0.269 * * \\
(0.105)\end{array}$ \\
\hline$\Delta$ young & & & & & $\begin{array}{l}-0.336^{*} \\
(0.174)\end{array}$ & $\begin{array}{l}-0.386^{* * *} \\
(0.187)\end{array}$ \\
\hline$\Delta$ women & & & & & $\begin{array}{l}114.3 * * * \\
(28.80)\end{array}$ & $\begin{array}{l}125.1 * * * \\
(28.71)\end{array}$ \\
\hline$\Delta$ population & & & & & $\begin{array}{l}-0.0173 \\
(0.0188)\end{array}$ & $\begin{array}{l}-0.0373^{*} \\
(0.0225)\end{array}$ \\
\hline$\Delta \operatorname{tax}$ & & & & & $\begin{array}{l}0.00232 \\
(0.0919)\end{array}$ & $\begin{array}{l}-0.0185 \\
(0.0982)\end{array}$ \\
\hline$\Delta$ grants & & & & & $\begin{array}{l}0.00005 \\
(0.00004)\end{array}$ & $\begin{array}{l}0.00005 \\
(0.00004)\end{array}$ \\
\hline Y1985 & $\begin{array}{l}-0.425 \\
(0.955)\end{array}$ & $\begin{array}{l}-0.559 * * \\
(0.238)\end{array}$ & $\begin{array}{l}-0.423 \\
(0.973)\end{array}$ & $\begin{array}{l}-0.423 \\
(0.973)\end{array}$ & $\begin{array}{l}-1.234 \\
(0.969)\end{array}$ & $\begin{array}{l}-0.563 \\
(0.903)\end{array}$ \\
\hline Y1988 & $\begin{array}{l}-3.333 * * * \\
(0.410)\end{array}$ & $\begin{array}{l}-2.020 * * * \\
(0.253)\end{array}$ & $\begin{array}{l}-3.335^{* * *} \\
(0.409)\end{array}$ & $\begin{array}{l}-3.335 * * * \\
(0.409)\end{array}$ & $\begin{array}{l}-4.098 * * * \\
(0.449)\end{array}$ & $\begin{array}{l}-3.377 * * * \\
(0.442)\end{array}$ \\
\hline Y1991 & $\begin{array}{l}-5.763 * * * \\
(0.473)\end{array}$ & $\begin{array}{l}-5.602 * * * \\
(0.172)\end{array}$ & $\begin{array}{l}-5.759 * * * \\
(0.483)\end{array}$ & $\begin{array}{l}-5.759 * * * \\
(0.483)\end{array}$ & $\begin{array}{l}-5.487 * * * \\
(0.436)\end{array}$ & $\begin{array}{l}-5.692 * * * \\
(0.366)\end{array}$ \\
\hline Y1994 & $\begin{array}{l}4.276^{*} \\
(2.191)\end{array}$ & $\begin{array}{l}-1.876^{* * * *} \\
(0.692)\end{array}$ & $\begin{array}{l}4.263 * \\
(2.226)\end{array}$ & $\begin{array}{l}4.263 * \\
(2.226)\end{array}$ & $\begin{array}{l}5.344 * * * \\
(1.702)\end{array}$ & $\begin{array}{l}4.358 * * \\
(2.101)\end{array}$ \\
\hline Y1998 & $\begin{array}{l}-9.998 * * * \\
(0.606)\end{array}$ & $\begin{array}{l}-9.051 * * * \\
(0.207)\end{array}$ & $\begin{array}{l}-9.997 * * * \\
(0.614)\end{array}$ & $\begin{array}{l}-9.997 * * * \\
(0.614)\end{array}$ & $\begin{array}{l}-10.50 * * * \\
(0.757)\end{array}$ & $\begin{array}{l}-9.903 * * * \\
(0.706)\end{array}$ \\
\hline Y2002 & $\begin{array}{l}-1.307 \\
(0.943)\end{array}$ & $\begin{array}{l}1.830 * * * \\
(0.330)\end{array}$ & $\begin{array}{l}-1.299 \\
(0.950)\end{array}$ & $\begin{array}{l}-1.299 \\
(0.950)\end{array}$ & $\begin{array}{l}-1.644 * * \\
(0.712)\end{array}$ & $\begin{array}{l}-1.057 \\
(0.835)\end{array}$ \\
\hline Constant & No & No & No & No & No & No \\
\hline Elections & 6 & 6 & 6 & 6 & 6 & 6 \\
\hline Weighted LS & Yes & Yes & Yes & Yes & Yes & Yes \\
\hline Observations & 1704 & 1692 & 1692 & 1692 & 1622 & 1622 \\
\hline Adj. $R^{2}$ & 0.89 & 0.90 & 0.90 & 0.90 & 0.90 & 0.90 \\
\hline
\end{tabular}

Note: Observations weighted by number of voters. Standard errors clustered on municipalities in parentheses. One, two and three stars denote statistical significance at the 10,5 and 1 percent level. $\mathrm{U}$ and $\mathrm{G}$ refer to unemployment and growth, subscripts $\mathrm{M}$ and $\mathrm{R}$ to municipality and region. 
So far, we have been able to control for common election specific effects and municipality fixed effects. To ensure that our estimates are not biased due to omitted time variant characteristics of the municipalities, we add seven control variables, capturing changes in demographic structure, taxes, and grants received from the central government, in column 5. Demographic variables are commonly used to predict party choice rather than government support and therefore, all five demographic variables and the change in local tax rate are multiplied by minus one for the 1994 election when there was a center-right government. Adding these variables does not lead to any significant changes in the estimates of interest from column 4. The effect of growth at the regional level increases somewhat but remains statistically insignificant. However, we note that increasing shares of foreign and women (old and young) are associated with an increase (decrease) in support for the Social Democratic Party. Changes in taxes and grants show no statistically significant effects on government support. Although excluding or including these variables only marginally affects the coefficients of interest in this paper, I choose to include them in subsequent specifications as well. At this point, we can be reasonably confident that bias stemming from omitted variables is not seriously confounding our results. ${ }^{18}$

In column 6, I investigate whether voters punish or reward the national incumbent for local economic conditions, depending on whether the municipality government is of the same type as the national government. For example, if local economic conditions are improving and the Social Democrats are incumbents both at the national and the municipality level, then some voters could conclude that policies by the Social Democrats are beneficial for their municipality or region. If the municipality and national governments are of different types, it may be less clear what type of policy has caused the economic outcomes. The results are obtained by interacting all economic conditions with a dummy variable taking the value of one if the local incumbent belongs to the same political bloc as the national incumbent. The results point to a slightly smaller response to economic growth at the regional level in municipalities where the incumbent belongs to the same political bloc as the national government. However, we still do not know whether any voters really respond to economic growth at all. These results indicate that when voting in the national election, citizens may only to a limited extent condition their responses to local economic conditions on whether the municipality government is of the same type as the national government.

Taken together, these results indicate that voters respond to unemployment at both the regional and municipality levels. What do these results say about the importance of local economic circumstances for voting behavior? The results from column 5 imply that at the regional and municipality levels, a one percentage point decrease in unemployment is associated with 1.71 and 0.43 percentage points higher support for the incumbent government, respectively. While growth at the municipality level does not seem to have any influence on central government support, a one percentage point increase in regional growth is associated with a 0.38 percentage points increase in support (although statistically insignificant). Are these effects substantial? The standard deviation of regional growth and unemployment is 2.8 and 2.3 , respectively. A one percentage point change in unemployment can therefore not be

\footnotetext{
${ }^{18}$ At this point we could consider dropping the growth variables from the regressions. I have done that and the unemployment coefficients changes only marginally (results available upon request).
} 
considered as an unusually large change in these variables, indicating substantial voting responses to unemployment both at the regional and municipality levels.

Although this dataset is not suited for estimating effects of national level economic conditions, it is nevertheless interesting to relate the effects of local economic conditions to the effects of macroeconomic variables. The election year effects in Table 3 suggest that changes in national level variables play an important role in explaining voting behavior. The year dummies, capturing the effects of changes at the macro level, explain a great deal of the variation in the change of government support, indicating that we cannot rule out important effects of national-level economic conditions. The largest estimates are found for the election in 1998, an election where the Social Democratic Party received the lowest support since the introduction of the unicameral system in 1970.

These dummies, however, do not only capture the effects of economic variables but all effects at the national level. This makes it difficult to infer from these estimates that growth and unemployment at the national level are important. However, many studies have estimated effects of national level economic variables. In their survey of the economic voting literature, Nannestad and Paldam (1994) conclude that in most studies, a one percentage point decrease in unemployment is associated with an increase in government support of between 0.4 and 0.8 percentage points, and that growth measures sometimes are more and sometimes less important than unemployment. Markus (1988) finds an unusually large effect of real disposable income per capita. A one percentage point increase is associated with a 2.3 percentage point increase in the vote share of incumbent American presidents. However, he does not control for changes in unemployment which may explain why the effect of growth was unusually high. Jordahl (2006) analyzes Swedish elections between 1985 and 1994 and finds that a one standard deviation decrease in unemployment is associated with a 17 percentage point increase in the probability of voting for the governing bloc, but no or small effects of growth. The overall impression, although with some exceptions, is that the effects of national level economic variables are of the same order of magnitude as those found at the regional level here. It is difficult to say whether the estimated effects of national level economic variables would change if measures of regional level variables were to be included in such analyses. But it seems plausible to believe that the effects of national level variables are biased upwards when local level measures are excluded. Together, these results indicate that unemployment at local levels may be at least as important for voting behavior as national level economic variables.

\subsection{Time horizon of voters}

So far, we have assumed that voters respond to economic conditions during the full term of office. The literature on political business cycles suggests that voters respond more to economic conditions closer to the election. Therefore, it might be argued that the regression model should be specified with economic variables that give a higher weight to economic conditions closer to the elections. As a sensitivity check, I have repeated the analysis with two different measures of economic conditions. The results are presented in Table 4. Column 1 is reproduced from Table 3, column 5. In column 2, the four measures of economic conditions are calculated as differences between the two years preceding the election and the two years preceding the previous election. In column 3, only the differences in the economic conditions 
between election years are included. The results indicate that changes in growth, at the regional level, may be more important closer to the elections. The coefficient increases in size and becomes statistically significant. The effect of growth at the municipality level is in all three specifications close to zero, but statistically significant at the ten percent level in column 3. The coefficients for unemployment decrease somewhat at both levels. Although some differences in size and statistical significance is found between the three specifications, the results do not seem to critically depend on what time-horizon we assume voters to have.

Table 4

Voters' time horizon

\begin{tabular}{llll}
\hline & $(1)$ & $(2)$ & $(3)$ \\
Dep. Var. & $\Delta \mathrm{Gov}$ & $\Delta \mathrm{Gov}$ & $\Delta \mathrm{Gov}$ \\
Time horizon & Full term & Last two years & Election year \\
\hline$\Delta \mathrm{G}_{\mathrm{R}}$ & 0.382 & $0.661^{* * *}$ & $0.540^{* * * *}$ \\
& $(0.251)$ & $(0.120)$ & $(0.0684)$ \\
$\Delta \mathrm{U}_{\mathrm{R}}$ & $-1.711^{* * *}$ & $-1.567 * * *$ & $-1.212^{* * *}$ \\
& $(0.339)$ & $(0.473)$ & $(0.412)$ \\
$\Delta \mathrm{G}_{\mathrm{M}}$ (transformed) & 0.00222 & 0.0162 & $0.0322^{*}$ \\
& $(0.0388)$ & $(0.0329)$ & $(0.0172)$ \\
$\Delta \mathrm{U}_{\mathrm{M}}$ (transformed) & $-0.427 * * *$ & $-0.158^{*}$ \\
& $(0.118)$ & $-0.264 * * *$ & $(0.0932)$ \\
Controls & Yes & $(0.0908)$ & Yes \\
Year dummies & Yes & Yes & Yes \\
Constant & No & Nos & 6 \\
Elections & 6 & 6 & 1624 \\
Observations & 1622 & 1624 & 0.90 \\
Adj. $\mathrm{R}^{2}$ & 0.90 & 0.90 & No \\
\hline Note: Observations weighted by number of voters. Standard errors clustered on municipalities in parentheses. One, two and \\
three stars denote statistical significance at the 10, 5 and 1 percent level. U and G refer to unemployment and growth, \\
subscripts M and R to municipality and region. All three specifications include the same set of control variables and year \\
dummies as in Table 3, column 5.
\end{tabular}

\subsection{Differences in type of government}

An implicit assumption in the empirical investigation so far has been that voters hold the parties represented in the government responsible for local economic conditions. Typically, studies of economic voting in Sweden analyze how support for the governing bloc depends on economic conditions. The reason for treating the Swedish system as a two-party system is that the parties within the two blocs tend to cooperate to a large extent. The center-right bloc has formed coalition governments where almost the entire bloc has been included. ${ }^{19}$ The Social Democratic Party, on the other hand, has ruled as a minority government and has therefore been forced to seek support from other parties. During the period covered in this study, the Social Democratic Party has cooperated intensively with the Left Party and for extended periods also with the Green Party and the Center Party. Thus, it is possible that voters do not only hold the Social Democratic Party responsible for the economic conditions but also the cooperating parties. As a consequence, it may be motivated to treat the Swedish system as a two-party system and investigate changes in the support of the governing bloc.

On the other hand, it could also be the case that not even all parties within the government, but only the largest party, is held responsible for economic conditions. For the time period

\footnotetext{
${ }^{19}$ In 1991 to 1994, the New Democrats (Ny Demokrati) were represented in parliament and gave their support to the center-right bloc, but they were not included in the government.
} 
under study, only one government has consisted of more than one party (the center-right government that ruled from 1991 to 1994), thus making it difficult to test with a reasonable degree of certainty whether such a conjecture is supported. By comparing the results obtained with four alternative dependent variables, we may nevertheless obtain some tentative indications of how voters punish and reward leading parties.

Table 5 displays such results. Column 1 is reproduced from Table 3 , column 5 , to facilitate the comparison. Column 2 shows the results when the whole bloc is included in the dependent variable. The main difference between column 1 and 2 is at the municipality level. Although still small the effect of growth becomes statistically significant and the effect of unemployment is smaller and statistically insignificant. During 1991 to 1994, the New Democrats, a party of discontent, supported the center-right government. This party was the only center-right party that was not part of the coalition government. The party was founded in 1991 and received 6.7 percent of the votes in 1991. In 1994, however, they received only 1.4 percent of the votes and virtually disappeared from the national political arena. The drop in support for the center-right bloc, in 1994, is therefore roughly 12 percentage points if the New Democrats are included and only about 6 percentage points if they are excluded. In column 3, the New Democrats have been excluded from the center-right bloc, resulting in estimates that are more similar to those in column 1. The main difference is that the effect of growth is statistically significant at both levels. In column 4, we instead restrict the dependent variable to only include the largest party in the government. The results are very similar to those in column 1. Comparing the four specifications indicates that the qualitative conclusions do not depend on how the dependent variable is defined. The overall impression is that also parties supporting the government are held responsible for economic conditions, but we cannot say if they are held responsible to the same degree as the largest party or those represented in the government. ${ }^{20}$

\footnotetext{
${ }^{20}$ It would be interesting to also analyze whether responses are heterogeneous for left and center-right governments as suggested by the clientele hypothesis (Rattinger, 1980), the salient goal hypothesis (Powell and Whitten, 1993), or by variations in demand for social insurance (Markussen, 2008). We have only one centerright government in the sample which also differs in that this government was a majority coalition government, while the others have been single-party minority governments. Furthermore, Sweden experienced a severe economic downturn during this period, making it very hard to disentangle causes of potential heterogeneity. Such an analysis is therefore not meaningful with the current data.
} 
Table 5

Robustness with respect to governing bloc or party as dependent variable?

\begin{tabular}{lllll}
\hline & $(1)$ & $(2)$ & $(3)$ & $(4)$ \\
Dep. Var. & $\Delta \mathrm{Gov}$ & $\Delta$ Bloc (alt 1) & $\Delta$ Bloc (alt 2) & $\Delta$ Biggest party \\
\hline$\Delta \mathrm{G}_{\mathrm{R}}$ & 0.382 & 0.248 & $0.491^{* * *}$ & 0.276 \\
& $(0.251)$ & $(0.186)$ & $(0.204)$ & $(0.279)$ \\
$\Delta \mathrm{U}_{\mathrm{R}}$ & $-1.711^{* * *}$ & $-1.792^{* * *}$ & $-1.598^{* * *}$ & $-1.232^{* * *}$ \\
& $(0.339)$ & $(0.463)$ & $(0.491)$ & $(0.204)$ \\
$\Delta \mathrm{G}_{\mathrm{M}}$ (transformed) & 0.00222 & $0.145^{* * *}$ & $0.109^{* * *}$ & -0.0953 \\
& $(0.0388)$ & $(0.0368)$ & $(0.0331)$ & $(0.0840)$ \\
$\Delta \mathrm{U}_{\mathrm{M}}$ (transformed) & $-0.427 * * *$ & -0.142 & $-0.265^{* * *}$ & $-0.324 * * *$ \\
& $(0.118)$ & $(0.0949)$ & $(0.0943)$ & $(0.0656)$ \\
Controls & Yes & Yes & Yes & Yes \\
Year Dummies & Yes & Yes & Yes & Yes \\
Constant & No & No & No & No \\
Elections & 6 & 6 & 6 & 6 \\
Observations & 1622 & 1622 & 1622 & 1622 \\
Adj. $\mathrm{R}^{2}$ & 0.90 & 0.91 & 0.83 & 0.90 \\
\hline
\end{tabular}

Notes: Observations weighted by number of voters. Alt 1 includes the New Democrats in the right-wing bloc. Alt 2 excludes the New Democrats from the center-right bloc. Standard errors clustered on municipalities in parentheses. One, two and three stars denote statistical significance at the 10,5 and 1 percent level. $\mathrm{U}$ and $\mathrm{G}$ refer to unemployment and growth, subscripts $\mathrm{M}$ and $\mathrm{R}$ to municipality and region. All four specifications include the same set of control variables and year dummies as in Table 3, column 5

\section{Concluding remarks}

Empirical studies of economic voting have traditionally not included local economic conditions in their analyses. Johnston and Pattie (2001) questioned this methodology and showed that in the British General Election in 1997, voters responded strongly to economic conditions in "their part" of Britain. Furthermore, empirical studies related to the literature on tactical redistribution have shown that citizens respond to central government spending in local districts and municipalities (Levitt and Snyder, 1997 and Jordahl, 2002).

Using data covering six elections, this paper has improved the understanding of how voters respond to local economic conditions by estimating responses to the most commonly used measures of economic conditions, viz. economic growth and unemployment. The empirical investigation points to substantial responses to changes in unemployment at the regional level. The estimated responses to growth, at the regional level, are substantial in size, but statistically insignificant in most specifications. The preferred specification suggests that increasing regional growth or reducing regional unemployment by one percentage point is associated with an increase in the vote share for the government by 0.38 and 1.71 percentage points, respectively, from voters in that region. The effect of unemployment is lower at the municipality level than at the regional level, but it is still statistically significant in most specifications, while the effect of growth is close to zero. One possible, although speculative, explanation for the small responses to municipality-level economic conditions could be that voters consider the local governments to be responsible for growth and unemployment in the municipalities.

Exposing the results to various robustness tests does not change the overall picture that voters seem to respond to changes in unemployment at both the regional and municipality level and that voters may also, to some degree, respond to changes in growth at the regional level. 
Together the results indicate that local economic conditions are of importance for how citizens vote and may be fruitfully included in empirical voting equations. If measures of local economic conditions are omitted, then estimates of other variables may be biased and misleading. This paper also shows that voters do not only respond to local spending by the central government, but also to traditional measures of economic outcomes. This further justifies the assumption in models of political behavior that voters are sensitive to local levels of economic conditions. 


\section{Appendix A: Description of data}

$\Delta$ Gov: The change in the vote share of the parties forming the government. For example, at the election in 1994, it is calculated as the total vote share of the four center-right parties forming the coalition government 1991 to 1994 at the election in 1994 minus the total vote share of the same parties at the election in 1991. In the 1994 election, this variable consists of the Moderate Party, the Center Party, the Liberal Party, and the Christian Democrats (Kristdemokraterna) and in all other elections of the Social Democratic Party (Socialdemokraterna). Unit: percentage points. Source: www.scb.se.

$\Delta$ Bloc: The change in the vote share of the governing bloc. For example, at the election in 1994 it is calculated as the total vote share of the five center-right parties in 1994 minus the total vote share of the same parties at the election in 1991. The left bloc is defined as the Social Democratic Party, the Left Party, and the Green Party and it is being used at the elections in 1985, 1988, 1991, 1998 and 2002. The center-right bloc is defined as consisting of the Moderate Party, the Center Party, the Liberal Party, and the Christian Democrats, and the New Democrats (Ny demokrati) and is being used at the elections in 1982 and 1994. Unit: percentage points. Source: www.scb.se.

$\Delta \mathbf{U}_{\mathbf{M}}$ : The change in the mean unemployment rate between two elections. For example, at the election in 2002, it is calculated as the arithmetic mean of the unemployment rate for 1999, 2000, 2001, and 2002, minus the mean unemployment for 1995, 1996, 1997, and 1998. The unemployment rate is calculated as the number of unemployed divided by the population aged 16-64. Unit: Percentage points. Source: www.ams.se.

$\Delta \mathbf{G}_{\mathbf{M}}$ : The change in the mean of the growth rate of the tax base in the municipality between two elections. For example, at the election in 2002, it is calculated as the geometric mean of the tax base for 1999, 2000, 2001, and 2002, minus the tax base for 1995, 1996, 1997, and 1998. The tax base is deflated by CPI. Unit: Percentage points. Source: www.scb.se.

$\Delta \mathbf{U}_{\mathbf{R}}$ : The change in the weighted mean of $\Delta U_{M}$ of all municipalities in each region. The weights are proportional to the municipalities' share of the population in the region. Unit: Percentage points.

$\Delta \mathbf{G}_{\mathbf{R}}$ : The weighted mean of $\Delta \mathrm{U}_{\mathrm{M}}$ of all municipalities in each region. The weights are proportional to the municipalities' share of the population in the region. Unit: Percentage points.

$\Delta \mathbf{U}_{M}($ transformed $): \Delta \mathbf{U}_{M}($ transformed $)=\Delta \mathbf{U}_{M}-\Delta \mathbf{U}_{\mathbf{R}}$

$\Delta \mathbf{G}_{\mathrm{M}}($ transformed $): \Delta \mathbf{G}_{\mathrm{M}}($ transformed $)=\Delta \mathbf{G}_{\mathrm{M}}-\Delta \mathbf{G}_{\mathrm{R}}$

$\Delta$ foreign: The change in the fraction of foreign citizens since the last election year in each municipality. Unit: Percentage points. Source: www.scb.se.

$\Delta$ old: The change in the fraction of people aged 65 or older since the last election year in each municipality. Unit: Percentage points. Source: www.scb.se.

$\Delta$ young: The change in the fraction of people aged 18 or younger since the last election year in each municipality. Unit: Percentage points. Source: www.scb.se. 
$\Delta$ women: The change in the fraction of women since the last election year in each municipality. Unit: Percentage points. Source: www.scb.se.

$\Delta$ population: The change in municipality population since the last election year. Unit: citizens. Source: www.scb.se.

$\Delta$ tax: The change in the local tax rate since the last election year. Unit: Percentage points. Source: Statistics Sweden.

$\Delta$ grants: The change in grants from the central government since the last election year. Unit: SEK/Capita. Source: Statistics Sweden.

Table A1

Summary statistics by election

\begin{tabular}{|c|c|c|c|c|c|c|}
\hline Variable & Year & Obs. & Mean & Std. Dev. & Min. & Max. \\
\hline$\Delta \mathrm{Gov}$ & 1985 & 284 & -0.49 & 1.08 & -4.09 & 2.77 \\
\hline$\Delta \mathrm{G}_{\mathrm{R}}$ & 1985 & 284 & 3.72 & 0.32 & 3.20 & 4.37 \\
\hline$\Delta \mathrm{U}_{\mathrm{R}}$ & 1985 & 284 & 0.61 & 0.25 & -0.16 & 0.98 \\
\hline$\Delta \mathrm{G}_{\mathrm{M}}$ & 1985 & 284 & 4.13 & 1.34 & -3.95 & 13.75 \\
\hline$\Delta \mathrm{U}_{\mathrm{M}}$ & 1985 & 279 & -0.51 & 0.72 & -5.83 & 2.93 \\
\hline$\Delta$ Gov & 1988 & 284 & -0.66 & 1.43 & -5.16 & 2.79 \\
\hline$\Delta G_{R}$ & 1988 & 284 & 3.02 & 0.64 & 2.15 & 4.14 \\
\hline$\Delta \mathrm{U}_{\mathrm{R}}$ & 1988 & 284 & -0.93 & 0.21 & -1.19 & -0.41 \\
\hline$\Delta \mathrm{G}_{\mathrm{M}}$ & 1988 & 284 & 2.50 & 1.64 & -13.45 & 9.62 \\
\hline$\Delta \mathrm{U}_{\mathrm{M}}$ & 1988 & 278 & -1.01 & 0.57 & -3.22 & 0.27 \\
\hline$\Delta$ Gov & 1991 & 284 & -5.43 & 1.66 & -10.68 & 0.01 \\
\hline$\Delta \mathrm{G}_{\mathrm{R}}$ & 1991 & 284 & -2.04 & 0.68 & -2.73 & -0.93 \\
\hline$\Delta \mathrm{U}_{\mathrm{R}}$ & 1991 & 284 & -0.51 & 0.29 & -0.89 & -0.03 \\
\hline$\Delta \mathrm{G}_{\mathrm{M}}$ & 1991 & 284 & -1.78 & 1.20 & -6.94 & 2.33 \\
\hline$\Delta \mathrm{U}_{\mathrm{M}}$ & 1991 & 284 & -0.53 & 0.55 & -2.90 & 0.92 \\
\hline$\Delta$ Gov & 1994 & 284 & -5.77 & 2.04 & -11.28 & 8.10 \\
\hline$\Delta \mathrm{G}_{\mathrm{R}}$ & 1994 & 284 & -2.41 & 0.26 & -2.93 & -2.10 \\
\hline$\Delta \mathrm{U}_{\mathrm{R}}$ & 1994 & 284 & 5.67 & 0.29 & 5.20 & 6.13 \\
\hline$\Delta \mathrm{G}_{\mathrm{M}}$ & 1994 & 284 & -2.34 & 1.14 & -5.60 & 2.65 \\
\hline$\Delta \mathrm{U}_{\mathrm{M}}$ & 1994 & 284 & 5.46 & 1.09 & 1.69 & 7.98 \\
\hline$\Delta$ Gov & 1998 & 284 & -8.68 & 2.52 & -17.73 & -2.70 \\
\hline$\Delta \mathrm{G}_{\mathrm{R}}$ & 1998 & 284 & 2.90 & 0.27 & 2.41 & 3.24 \\
\hline$\Delta \mathrm{U}_{\mathrm{R}}$ & 1998 & 284 & -0.53 & 0.24 & -0.91 & -0.19 \\
\hline$\Delta \mathrm{G}_{\mathrm{M}}$ & 1998 & 284 & 2.85 & 0.80 & -0.06 & 6.27 \\
\hline$\Delta \mathrm{U}_{\mathrm{M}}$ & 1998 & 284 & -0.61 & 0.76 & -2.78 & 1.95 \\
\hline$\Delta$ Gov & 2002 & 284 & 3.61 & 2.07 & -8.22 & 8.78 \\
\hline$\Delta \mathrm{G}_{\mathrm{R}}$ & 2002 & 284 & 1.67 & 0.30 & 1.32 & 2.30 \\
\hline$\Delta \mathrm{U}_{\mathrm{R}}$ & 2002 & 284 & -2.76 & 0.15 & -3.01 & -2.51 \\
\hline$\Delta \mathrm{G}_{\mathrm{M}}$ & 2002 & 284 & 1.41 & 0.74 & -1.12 & 3.56 \\
\hline$\Delta \mathrm{U}_{\mathrm{M}}$ & 2002 & 284 & -2.68 & 0.81 & -5.25 & 0.80 \\
\hline
\end{tabular}

Note: Changes in economic growth and unemployment measures are based on full-term averages. 


\section{Appendix B: Description of regions}

Table B1

Description of regions

\begin{tabular}{lll}
\hline Region & Number of municipalities & Population (1990) \\
\hline Nordnytt region & 29 & 515,703 \\
Mittnytt region & 15 & 396,881 \\
Gävledala region & 25 & 578,361 \\
Tvärsnytt region & 38 & 814,110 \\
ABC region (Capital) & 34 & $1,910,504$ \\
Östnytt region & 23 & 715,755 \\
Västnytt region & 55 & $1,712,891$ \\
Smålandsnytt region & 33 & 727,274 \\
Sydnytt region & 38 & $1,219,151$ \\
\hline
\end{tabular}

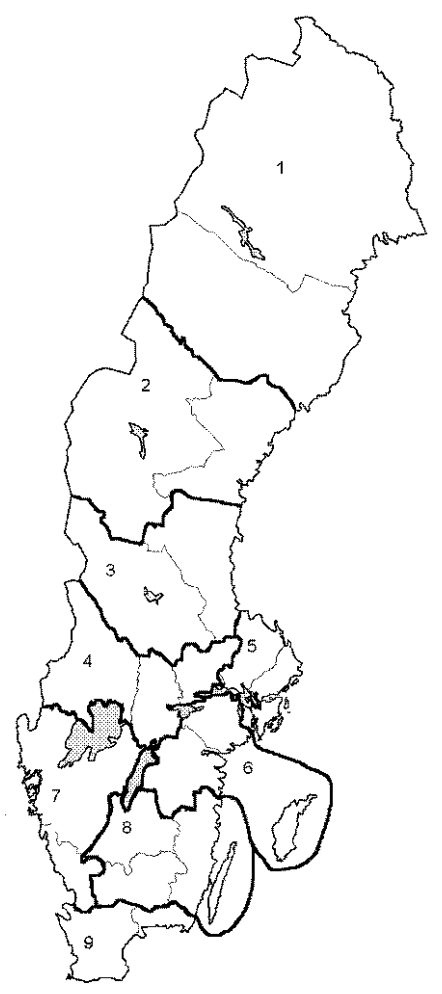

\section{Map of Regions}

1. The "Nordnytt" region

2. The "Mittnytt" region

3. The "Gävledala" region

4. The "Tvärsnytt" region

5. The " $\mathrm{ABC}$ " region (The capital region)

6. The "Östnytt" region

7. The "Västnytt" region

8. The "Smålandsnytt" region

9. The "Sydnytt" region

Thick line denotes region border

Thin line denotes county border

Fig. 1. Map of regions. Source: Statistics Sweden. 


\section{References}

Auberger, A,. Dubois, E., 2005. The influence of local and national economic conditions on French legislative elections. Public Choice 125, 363-383.

Alesina, A,. Roubini, N., Cohen, G., 1997. Political Cycles and the Macroeconomy. MIT Press, Cambridge.

Antoni, R., Eriksson, T., 2002. Läsvanestudien: arbetsrapport nr.7. (Report on reading habits of daily newspapers) The Department of Journalism and Masscommunication, University of Gothenburg.

Blomquist, S., Christiansen, V., 1999. The political economy of publicly provided private goods. Journal of Public Economics 73, 31-54.

Brennan, G., Lomasky, L., 1993. Democracy and Decision: The Pure Theory of Electoral Preferences. Cambridge University Press, New York.

Cox, G., McCubbins, M., 1986. Electoral politics as a redistributive game. The Journal of Politics 48, 370-389.

Davidson, R., MacKinnon, J.G., 2004. Econometric Theory and Methods. Oxford University Press, New York.

Dixit, A., Londregan, J., 1996. The determinants of success of special interests in redistributive politics. The Journal of Politics 58, 1132-1155.

Dixit, A., Londregan, J., 1998. Ideology, tactics, and efficiency in redistributive politics. The Quarterly Journal of Economics 113, 497-529.

Downs, A., 1957. An Economic Theory of Democracy. Harper and Row, New York.

Duch, R., Palmer, H., Anderson, C., 2000. Heterogeneity in perceptions of economic conditions. American Journal of Political Science 44, 635-652.

Eisenberg, D., Ketcham, J., 2004 Economic voting in U.S. presidential elections: who blames whom for what. Topics in Economic Analysis \& Policy 4.

Greene, W.H., 2004. Econometric Analysis. Prentice Hall. Upper Saddle River.

Johnston, R.J., Pattie, C.J., 2001. 'It's the economy, stupid' - but which economy? Geographical scales, retrospective economic evaluations and voting at the 1997 British general election. Regional Studies 35, 309-319.

Jordahl, H., 2002. The impact of grants on election outcomes: evidence from Swedish municipalities. in Essays on Voting Behavior, Labor Market Policy, and Taxation. Doctoral dissertation, Uppsala University, Department of Economics.

Jordahl, H., 2006. An economic analysis of voting in Sweden. Public Choice 127, 251-265. 
Key, V.O., 1966. The Responsible Electorate: Rationality in Presidential Voting 1936-1960. Harvard University Press, Cambridge.

Kinder, D.R., Kiewiet, D.R., 1979. Economic discontent and political behavior: the role of personal grievances and collective economic judgments in congressional voting. American Journal of Political Science 23, 495-527.

Kirchgässner, G., 1991. On the relation between voting intention and the perception of the general economic situation. An empirical analysis for the Federal Republic of Germany, 1972-1986. European Journal of Political Economy 7, 497-526.

Kramer, G., 1971. Short-term fluctuations in U.S. voting behavior, 1896-1964. American Political Science Review 65, 131-143.

Kramer, G., 1983. The ecological fallacy revisited: aggregate vs. individual-level findings on economics and elections, and sociotropic voting. American Political Science Review 77, $131-143$.

Leigh, A., 2005. Economic voting and electoral behavior: how do individual, local, and national factors affect the partisan choice? Economics and Politics 17, 265-96.

Levitt S, Snyder J (1997) The impact of federal spending on house election outcomes. Journal of Political Economy 105 (1): 30-53

Lewis-Beck M, Paldam M (2000) Economic voting: An introduction. Electoral Studies 19 $(2-3): 113-121$

Lewis-Beck, M., Stegmaier, M., 2000. Economic determinants of electoral outcomes. Annual Review of Political Science 3, 183-219.

Lindbeck, A., Weibull, J., 1993. A model of political equilibrium in a representative democracy. Journal of Public Economics 51, 195-209.

Markus, G., 1988. The impact of personal and national economic conditions on the presidential vote: a pooled cross-sectional analysis. American Journal of Political Science $32,137-154$.

Markussen, S., 2008. How the left prospers from prosperity. European Journal of Political Economy 24, 329-342.

Nannestad, P., Paldam, M., 1994. The VP-function: a survey of the literature on vote and popularity functions after 25 years. Public Choice 79, 213-245.

Nannestad, P., Paldam, M., 1997. From the pocketbook of the welfare man: a pooled crosssection study of economic voting in Denmark 1986-1992. British Journal of Political Science 27, 119-36.

Persson, T., Tabellini, G., 1990. Macroeconomic Policy, Credibility and Politics. Harwood Academic Publishers, London. 
Powell, G.B. Jr., Whitten, G.D., 1993. A cross-national analysis of economic voting: taking account of the political context. American Journal of Political Science 37, 391-414.

Rattinger, H., 1980. Wirtschaftliche Konjunktur und Politische Wahlen in der Bundesrepublik Deutschland. Dunker und Humblot, Berlin.

Rogoff, K., Sibert, A., 1988. Elections and macroeconomic policy cycles. Review of Economic Studies 55, 1-16.

Veiga, F., Veiga, L., 2008. The impact of local and national economic conditions on legislative election results. Applied Economics 99999:1, 1-8.

Weingast, B., Shepsle, A., Johnsen, C., 1981. The political economy of benefits and costs: neoclassical approach to distributive politics. Journal of Political Economy 89, 642-664.

Wooldridge, J.M., 2002. Econometric Analysis of Cross Section and Panel Data. The MIT Press, Cambridge. 